\title{
Environmental Education, Attitudes, and Behaviours of Nutrition and Dietetics Students on Buying Organic Foods
}

\author{
DOI: $10.26466 / o p u s .872561$
}

*

\author{
Nurhan Unusan* $^{*}$ Mustafa Agah Tekindal ${ }^{* *}$ \\ * Prof.Dr, KTO Karatay University, Konya/Turkey \\ E-Mail: $\quad$ nurhan.unusan@karatay.edu.tr \\ ORCID: $\quad \underline{0000-0002-7445-6903}$ \\ ** Assoc. Prof, İzmir Katip Çelebi University, Faculty of Medicine, İzmir/Turkey \\ E- Mail: matekindal@gmail.com \\ ORCID: $\quad \underline{0000-0002-4060-7048}$
}

\begin{abstract}
Environmental knowledge is a main determinant of organic food buying. This study investigated the relationships among nutrition and dietetics students' knowledge, attitudes, and behaviours toward organic foods as they are marketed as healthier and environment friendly. The participants included all fourth-year nutrition and dietetics undergraduate students at 3 faculties in Konya, Turkey. The Cronbach's alpha and factor loadings were calculated for the constructed indexes to check the reliability. The Kaiser-Meyer-Olkin test was conducted and the sample size was found to be sufficient. Bartlett's sphericity test was used to measure the suitability of the chi-square value for factor analysis. The factor analysis was performed on the obtained data of the questionnaire items using the Varimax method. The higher the ratio, the more suitable the data set is for factor analysis. The ANOVA Tukey's test of additivity was used to calculate the total score of the scale. It was found that students with a higher score on environment knowledge showed a more positive environmental attitude. Specifically, nutrition and dietetics students with more positive environmental attitudes showed positive environmental behaviours. Moreover, environmental knowledge, attitudes, and behaviours were significantly associated with increased frequency of purchasing organic food among students. This is the first research study to investigate the environmental knowledge, attitudes, and behaviours of nutrition and dietetics students, which are believed to be associated with their frequency of purchasing organic foods.
\end{abstract}

Key Words: Environmental Knowledge, Organic Food, Nutrition and Dietetics Students. 


\section{Beslenme ve Diyetetik Öğrencilerinin Organik Gıda Satın Alma Konusundaki Çevre Eğitimi, Tutum ve Davranışları}

Öz

Çevre bilgisi, organik gıda satın almanın temel belirleyicisidir. Bu çalışma, beslenme ve diyetetik öğrencilerinin daha sağllklı ve çevre dostu olarak pazarlanan organik gıdalara yönelik bilgi, tutum ve davranışları arasındaki ilişkileri araştırmıştır. Katılımcılar arasında Konya'da 3 fakültenin beslenme ve diyetetik lisans öğrencilerinin tamamı yer amıştırı. Güvenilirliği kontrol etmek için yapılandırılmış indeksler için Cronbach alfa ve faktör yükleri hesaplanmıştır. Kaiser-Meyer-Olkin testi yapılmış ve örneklem büyüklüğünün yeterli oldŭ̆u görülmüştür. Ki-kare değerinin faktör analizi için uygunluğunu ölçmek için Bartlett'in küresellik testi kullanılmıştır. Anket maddelerinin elde edilen verileri üzerinde Varimax yöntemi kullanılarak faktör analizi yapılmıştır. Oran ne kadar yüksekse, veri seti faktör analizi için o kadar uygundur. Ölçeğin toplam puanın hesaplamak için ANOVA Tukey'in toplamsallık testi kullanılmıştır. Çevre bilgisinden daha yüksek puan alan öğrencilerin daha olumlu bir çevre tutumu sergilediği görülmüştür. Özellikle, daha olumlu çevresel tutuma sahip beslenme ve diyetetik öğrencileri olumlu çevresel davranışlar sergilemişlerdir. Dahası, çevresel bilgi, tutumlar ve davranışlar, öğrenciler arasında organik gıda satın alma sıklı̆̆ının artmasıyla önemli ölçüde ilişkilendirilmiştir. Bu, beslenme ve diyetetik öğrencilerinin organik gıda satın alma sıklıklarn ile ilişkili olduğuna inanılan çevresel bilgi, tutum ve davranışlarım araştıran ilk araştırma çalışmasıdır.

Anahtar Kelimeler: Çevre Bilgisi, Organik Gıda, Beslenme ve Diyetetik Öğrencileri. 


\section{Introduction}

Environmental education is defined as a process that promotes awareness of the relationship between humans and their cultural and technological environments. It has been found to be an effective way to improve the environmental knowledge of students, which, in turn, positively affects the environmental attitudes of the students, further influencing their behaviour. However, investigating the relationship between the environmental attitudes and behaviours of students is a difficult process. The universities have the potential to educate the students regarding environmental sustainability through their education system, curriculum, syllabus, and practices. Therefore, it is crucial that universities incorporate environmental education into their curriculum as well as student activities (Lozano, Lozano, Mulder, Huisingh, and Waas, 2013).

Environmental knowledge can be defined as the individual's knowledge and awareness on environmental problems and the likely solutions to the problems. Any knowledge on the interrelation between individuals' life and their environment can be considered as environmental knowledge (Mantzicopoulos and Patrick, 2011). The essential elements for evaluating the environmental knowledge can include environmental conservation, air pollution, and water resource (Chang, 2011). Recent studies in environmental education have found influence on a one's intent to act responsibly; i.e. personality, skills, values, and attitudes (Bamberg and Möser, 2007). Considering that the individual's partial knowledge counts as an essential precondition for a person's behaviour, and most educational interventions concentrate on the knowledge transfer process (Kaiser, Roczen, and Bogner, 2008). Moreover, environmental knowledge has the capacity to develop positive environmental attitudes and behaviours, especially among students (Liefländer, Bogner, Kibbe, and Kaiser, 2015). Although the knowledge about environmental problems may pique the individual's interest and concern, it does not certainly result in positive changes in their behaviour (Kollmuss and Agyeman, 2002). For the environmental education to be effective and successful, strengthening the sense of responsibility among the students and academic professionals is definitely key, especially in universities where innovative methods are needed to prepare students 
effectively to deal with both sustainability and environmental issues. Therefore, the main objective of environmental education must be to foster behavioral change with regard to the environmental awareness (Zsóka, Szerényi, Széchy, and Kocsis, 2013).

Environmental attitudes are assumed as a vital predictor for environmental behaviour. Pro-environmental behaviour describes a behaviour that avoids harming the environment as far as possible, in a way that it benefits the environment. Moreover, pro-environmental attitudes are dependent on gender, age, experience, knowledge, cultural backgrounds, and rural-urban residences (Gifford, Sussman, and Clayton, 2012).

Research results regarding correlations between knowledge, attitudes, and behaviour remain inconsistent (Kollmuss and Agyeman, 2002), and environmental attitudes appear to be a minor predictor for proenvironmental behaviour. Environmental knowledge and proenvironmental attitudes are extremely interconnected. Environmental attitudes are defined as being composed of emotions and beliefs towards an object. These attitudes are evident in an individual's preference to attribute importance to various environmental activities. Moreover, an environmental attitude can be defined by an individual's characteristics that were developed over time. Those will be affected with environmental issues and in time take actions in environment protection (Chen, 2013). Researches yield mixed results regarding the relationship between behaviour and attitude alongside the effect of environmental education on attitude development (Drissner, Haase, and Hille, 2010; Johnson and Manoli, 2010). Environmental behaviour is defined as the behaviour manifested by a one or a group to work out a specific environmental problem (Hadzigeorgiou, Prevezanou, Kabouropoulou, and Konsolas, 2011). The changes in attitudes are insufficient to alter behaviour in a predictable manner (Szerényi, Ágnes, and Anna, 2011).

Organic farming aims to produce food products utilizing natural substances and processes. Producing organically means respecting the rules of organic farming that encourages the responsible use of natural resources and energy, maintenance of biodiversity, preservation of the regional ecological balance, water quality maintenance, soil fertility improvement, and building consumer trust in organic products. The 
European Union (EU) describes "organic farming" as a method of production that aims to produce high-quality products and the use of processes that are harmless to environment, humans, plants, or animals (Afonso, Gavilán, Martins Gonçalves, and García de Madariaga, 2017). While the EU organic market is continually expanding, just $6 \%$ of total EU agricultural area is used for organic agriculture that is a fast-growing field in EU agriculture, and it is the reason for the increased consumer interest in organic products. The EU has adopted a new legislation that will be effective on January 1, 2021 (EU, 2018). In Turkey, the number of organic farms was 14,401 in 2005 and increased to 75,067 in 2017 (MAF, 2020). Growing trends are observed in organic production (Boz and Kaynakçı, 2019). In 2018, Worldwide sales of organic foods amounted to 95 billion US dollars. In 2017, nearly 70 million hectares of organic farms were recorded worldwide. Moreover, 835,000 organic food producers are in India alone, which is more than any other country (Shahbandeh, 2020).

"Organic" is a labelling term defined by the United States Department of Agriculture A product must meet the federal standards for processing, production, and certification under the Organic Food Production Act of 1990 (Thalheimer and RD, 2013). Organic agriculture uses an approach towards raising livestock and growing crops that avoids antibiotic agents, hormones, synthetic chemicals, sewage sludge, genetic engineering, and irradiation. The animals must also have access to the outdoors. All feeds must be $100 \%$ organic, together with no animal by-products. To qualify as organic, crops must be produced in farms that do not use synthetic fertilizer, herbicides, and pesticides for three years before harvest and must provide a buffer zone to reduce contamination from nearby lands. Nutrient content and soil fertility are managed together with crop rotations, cultivation practices, and cover crops enhanced with crop and animal waste fertilizers. Weeds, pests, and diseases are controlled mainly by mechanical, physical, and biological controls rather than the use of synthetic herbicides and pesticides. Exceptions are permitted if the materials are on a national approved list. If an animal is treated with antibiotics, it cannot be sold as organic. Preventive health practices include vitamin and mineral supplementation and vaccination (Forman and Silverstein, 2012) . 
Consumers' perceptions regarding organic food consumption are influenced by food safety, price, age, gender, environmental knowledge, nutrition, and sensory attributes (Akgüngör, Miran, and Abay, 2010; Bramer, de Jonge, Rethlefsen, Mast, and Kleijnen, 2018; Çabuk, Tanrikulu, and Gelibolu, 2014; Ghali-Zinoubi, 2020; Muhammad, Fathelrahman, Ullah, and Ullah, 2016; Oraman and Unakitan, 2010; Sharma and Singhvi, 2018). Comparative health outcomes, together with safety of organic and conventional foods, and nutrition are deemed factors that influence the superiority of organic foods. However, it was shown that a higher number of women hold a more positive environmental attitude and purchase organic foods more often than men (Katt and Meixner, 2020). Also pregnant women (Konuk, 2018), and families with kids are more likely to buy organic foods (Aertsens, Verbeke, Mondelaers, and Huylenbroeck, 2009). The findings concerning education and age seem to be not consistent.

The research does not indicate marked health benefits from consuming conventional versus organic foods, although organic foods may decrease exposure to pesticide residues and organic meat may decrease exposure to antibiotic-resistant bacteria (Smith-Spangler et al., 2012). Dietitians also have to address the health needs of the population through a global food system, promoting consumption that supports sustainable agriculture, preservation of biodiversity and natural resources, waste reduction, and improvement in environmental sustainability (ICDA, 2010). organic food consumption behaviours and attitudes are strongly and consistently associated with any particular demographic variables (Baumann, Engman, Huddart-Kennedy, and Johnston, 2017). Attitude has a huge effect on the relationship between environmental knowledge and organic food intention (Indriani, Rahayu, and Hadiwidjojo, 2019). Environmental knowledge is a main determining factor of organic food buying. Since organic foods are marketed as environmentally friendly and being healthier, it is necessary to explore the relationships among nutrition and dietetics students' knowledge, attitude, and behaviour toward organic foods. Furthermore, the findings of this study could help educators and producers design the appropriate educational and marketing promotion strategies for organic food consumption. 


\section{Methods}

Ethical Approval: The ethical approval was obtained from the School of Medicine Research and Ethics Committee at Foundation University. All students were requested to sign the consent form before participating in the research. Confidentiality of the participants' information was ensured by not including the students' names and universities on the questionnaires. Self-administered questionnaires were distributed to all students and collected at once to minimize all-or-none response. The questionnaires were completed individually by final year nutrition and dietetics students during class time, supervised by the author.

Study Design and Sample Collection: The study was conducted from December 2018 to January 2019. Final year nutrition and dietetics students at 3 Universities in Konya/Turkey were invited to participate in the cross sectional survey. As part of their degree plan, the students in these programs were required to take a course in environmental issues. The choice of the 3 universities was based on willingness. One professor at each university undertook to get permission from faculty deans to have the questionnaire administered in their classes.

A pilot study with 15 undergraduate students was conducted in October 2018 in order to test the validity and the reliability and of the questions. Minor revisions were made based on the responses to the pilot survey. A convenience sampling method, which relies on the subjects available to the researcher, was utilized for this study. The findings of this study cannot be generalised the entire undergraduate population. The inclusion criteria of this study was that the student should have taken at least one environmental course.

Material: Enhancing the students' environmental knowledge and awareness can help alleviate some academic risks. However, this survey will in no way determine whether the students have the adequate knowledge to serve as an environmental professional. The data obtained from this study will serve as an initial evaluation of the level of environmental knowledge, attitudes, and behaviours. The questionnaire items were developed from earlier studies (Braun, 2018; Harding, 2016; 
Manoli et al., 2014) for future dietitians. Moreover, this study is exploratory in nature.

Each questionnaire had a short introductory section to brief the participants about the research objectives, and the instruction about the voluntarily basis of the evaluation. Data on environmental attitudes, knowledge, and behaviour of university students were collected from the questionnaire results. Internal consistency and reliability were examined. Thus, the final version of the survey consisted of 18 items written in English. Participants' gender (1 question) environmental knowledge (3 questions), behaviours (5 questions), and attitudes (8 questions) of the associations between preference for organic foods ( 1 question) were assessed using a 5 -point Likert scale (' $1=$ never', ' $2=$ rarely', ' $3=$ sometimes', ' $4=$ frequently', ' $5=$ always'). The relationship between two continuous variables was assessed by the Pearson correlation coefficient and the Spearman correlation coefficient when the parametric test prerequisites were not met.

Statistical Analysis: For data analyses, the Statistical Package for the Social Sciences (SPSS) software version 24 (SPSS Inc., Chicago, IL, USA) was used. Continuous variables were reported as mean and standard deviation (SD). The Cronbach's alpha $(\alpha)$ and factor loadings were calculated for the constructed indexes to check the reliability. The KaiserMeyer-Olkin test was conducted and the sample size was found to be sufficient. Bartlett's sphericity test was used to determine the suitability of the chi-square value for factor analysis. The factor analysis was performed on the data obtained from the questionnaire items using the Varimax method. The higher the ratio, the more suitable the data set is for factor analysis. ANOVA Tukey's test of additivity was used to calculate the total score of the scale. 
Environmental Education, Attitudes, and Behaviours of Nutrition and Dietetics Students on Buying Organic Foods

\section{Results}

Data were obtained from 207 participants. Among them, 8.7\% identified as male, and $91.3 \%$ as female, representing an unequal distribution of males and females. The questionnaire was found to have acceptable reliability (Cronbach's $\alpha>0.70$ ) and validity (loadings $>0.5$, eigenvalues $>$ $1)$. The Cronbach's $\alpha$ reliability coefficients for each construct are displayed in Table 1.

Table 1. Cronbach's a reliability coefficients for each question

\begin{tabular}{|c|c|c|c|c|}
\hline & $\begin{array}{c}\text { Scale } \\
\text { mean if } \\
\text { item } \\
\text { deleted }\end{array}$ & $\begin{array}{l}\text { Scale variance if } \\
\text { item deleted }\end{array}$ & $\begin{array}{l}\text { Corrected item- } \\
\text { total correlation }\end{array}$ & $\begin{array}{c}\text { Cronbach's } \alpha \\
\text { if item deleted }\end{array}$ \\
\hline $\begin{array}{l}\text { I turn the lights off when I } \\
\text { leave the room. }\end{array}$ & 60,6108 & 33,823 & 0,339 & 0,619 \\
\hline $\begin{array}{l}\text { I am careful enough not to } \\
\text { waste food. }\end{array}$ & 60,8424 & 33,975 & 0,345 & 0,619 \\
\hline $\begin{array}{l}\text { I am careful enough not to } \\
\text { waste water. }\end{array}$ & 60,7734 & 34,156 & 0,327 & 0,621 \\
\hline $\begin{array}{l}\text { I speak about environment to } \\
\text { my family and friends. }\end{array}$ & 61,4778 & 34,063 & 0,220 & 0,633 \\
\hline $\begin{array}{l}\text { I would love to join an } \\
\text { environment project in my } \\
\text { community. }\end{array}$ & 61,5172 & 31,479 & 0,359 & 0,610 \\
\hline \multicolumn{5}{|c|}{ Environmental attitude } \\
\hline $\begin{array}{l}\text { Plants, animal, and people } \\
\text { have equal rights to live. }\end{array}$ & 60,1527 & 34,387 & 0,385 & 0,619 \\
\hline $\begin{array}{l}\text { There are too many people on } \\
\text { Earth. }\end{array}$ & 60,4828 & 34,399 & 0,282 & 0,626 \\
\hline $\begin{array}{l}\text { People are very clever to keep } \\
\text { the Earth from ruining. }\end{array}$ & 61,3695 & 32,561 & 0,260 & 0,628 \\
\hline $\begin{array}{l}\text { People must obey the nature } \\
\text { laws. }\end{array}$ & 60,2759 & 34,240 & 0,311 & 0,623 \\
\hline $\begin{array}{l}\text { If people mess with nature, it } \\
\text { has bad results. }\end{array}$ & 60,3153 & 35,187 & 0,212 & 0,634 \\
\hline $\begin{array}{l}\text { Nature is strong enough to } \\
\text { handle the bad effects of } \\
\text { people' modern lifestyle. }\end{array}$ & 61,5911 & 34,282 & 0,216 & 0,654 \\
\hline $\begin{array}{l}\text { People are treating nature very } \\
\text { bad. }\end{array}$ & 60,6305 & 36,462 & 0,258 & 0,650 \\
\hline $\begin{array}{l}\text { If things do not change, there } \\
\text { will be a big disaster in the } \\
\text { environment very soon. }\end{array}$ & 60,6305 & 32,561 & 0,410 & 0,607 \\
\hline
\end{tabular}




\begin{tabular}{|c|c|c|c|c|}
\hline $\begin{array}{l}\text { If the producers in the } \\
\text { ecosystem reduces so does the } \\
\text { number of consumers. }\end{array}$ & 61,1773 & 31,859 & 0,268 & 0,628 \\
\hline $\begin{array}{l}\text { By getting a drive to school I } \\
\text { can reduce negative impact on } \\
\text { the environment. }\end{array}$ & 61,6158 & 33,673 & 0,250 & 0,650 \\
\hline $\begin{array}{l}\text { It is much better to } \\
\text { reduce/reuse than to recycle. }\end{array}$ & 60,7980 & 33,528 & 0,255 & 0,628 \\
\hline
\end{tabular}

No items with a Cronbach's $\alpha$ value less than 0.60 were observed in the survey. Since all the 16 items were of high reliability, no items were excluded. As a result of the application and item analysis, the results of the 16 items were quite favourable. Moreover, the reliability coefficient of the questionnaire was examined. The means to calculate the coefficient of reliability differ depending on the type of source and number of applications. The difference of the calculation path also affects the interpretative meaning of the reliability coefficient. The reliability coefficient is the degree of purity from accidental errors and gives information about the amount of error involved in the measurement results. Although reliability takes values ranging from 0 to +1 , it is required to take values close to +1 . Therefore, the reliability coefficient of more than 0.70 is a favourable result. Since each item uses a 5-point Likert scale, a reliability meaning was found in terms of reliability, Cronbach's $\alpha$ reliability, and internal consistency. The Cronbach's $\alpha$ coefficient of the questionnaire used in the research is shown in Table 2.

Table 2. Questionnaire items per construct and reliability

\begin{tabular}{ll}
\hline Construct & Cronbach' $^{\prime} \alpha$ \\
\hline Environmental knowledge & 0.78 \\
Environmental attitude & 0.70 \\
Environmental behaviour & 0.73 \\
Total Cronbach's Alpha $(\alpha)$ & 0.743 \\
\hline
\end{tabular}

The calculated Cronbach's $\alpha$ reliability coefficient was 0.743 . Therefore, the questionnaire was found to be suitable. In the validity study of the questionnaire, the factor analysis was made on the data obtained from the items in the questionnaire using the Varimax method (the findings are shown in the Table 3). When the total explained variance was analysed, it was concluded that three factors could be considered based on the application data for 15 items and the property was measured with this 
three-factor (environmental knowledge, environmental attitude, environmental behaviour) measurement tool. In the social sciences, a total explained variance of at least $55 \%$ was found to be sufficient. A KaiserMeyer-Olkin sample adequacy statistic above 0.50 is an indication of a sufficient sample size. Bartlett's sphericity test revealed that the data were suitable for factor analysis. Therefore, it can be said that these data are suitable for factor analysis $(\mathrm{p}<0.05)$. In general, it can be concluded that the validity of the measurement tool is dependent on the factor analysis results.

Table3. Total variance

\begin{tabular}{llll}
\hline Factor & \multicolumn{3}{l}{ Varimax rotation sums of squared factor loadings } \\
\hline $\mathbf{1}$ & Total & \% of variance & \% of cumulated variance \\
$\mathbf{2}$ & 2.79 & 18.61 & 18.61 \\
$\mathbf{3}$ & 2.76 & 22.00 & 40.61 \\
\hline
\end{tabular}

Kaiser-Meyer-Olkin (KMO) Test for Sampling Adequacy: 0.69

Bartlett's test of sphericity: 526.69

Degrees of freedom: $120 p=0.001$

As shown in Table 4, a statistically positive significant relationship was found between environmental attitude and environmental behaviour; as one increases, the other also increases $(79.1 \%)(p<0.01)$. A statistically significant relationship of $72.9 \%$ was found between environmental attitude and environmental knowledge $(\mathrm{p}<0.01)$. Additionally, a statistically significant relationship of $73 \%$ was found between the environmental behaviour and environmental knowledge $(\mathrm{p}<0.01)$.

Table 4. Relationship between environmental attitude, environmental knowledge, and environmental behaviour

Environmental behaviour Environmental attitude

\begin{tabular}{llll}
\hline Environmental attitude & $\mathrm{r}$ &, $791^{* *}$ & \\
& $\mathrm{p}$ & 0,001 &, $729^{* *}$ \\
Environmental knowledge & $\mathrm{r}$ &, $730^{* *}$ & 0,001 \\
\hline
\end{tabular}

${ }^{*} p<0.05 \quad{ }^{* *} p<0.001$

As shown in Table 5, environmental behaviours are significantly associated with preferring organic foods $(\mathrm{p}<0.001)$ that is also associated 
with environmental attitude $(\mathrm{p}<0.05)$, and environmental knowledge $(\mathrm{p}<0.001)$.

Table 5. Relationship between environmental attitude, environmental knowledge, environmental behaviour, and organic food preference

\begin{tabular}{ll}
\hline Environmental & Preferring organic foods \\
\hline Behaviour & $0.000^{* *}$ \\
Attitude & $0.013^{* *}$ \\
Knowledge & $0.001^{* *}$ \\
\hline
\end{tabular}

\section{Discussion}

This study aimed to explore the relationships among the nutrition and dietetics students' environmental knowledge, environmental attitude, and environmental behaviour in buying organic foods. Such outcomes deliver crucial information to education and agricultural sector. The results of this study show that students with a higher score of environmental knowledge manifest a more optimistic environmental attitude and vice versa. Students with more abundant environmental knowledge display more positive environmental behaviours and vice versa.

Therefore, it is important that environmental issues be taken seriously, considering the rapid development of science in the twenty-first century. The demand for organic foods has grown exponentially more than two decades. Additionally, the need for an improved environment and the increased demand for consumer and government action are also being considered. Moreover, environmental knowledge, attitude, and behaviour are significantly associated with the increased frequency of organic food purchase (Wheeler, Gregg, and Singh, 2019). The greatest task for environmental education is to educate, create, and stimulate internally motivated, committed and conscious students with a proenvironmental attitude (Zsóka et al., 2013), as they are essential drivers of a more sustainable future. In terms of the implications regarding stakeholders, the results indicate potential tools to stimulate the consumption of organic products. The credence characteristics of organic foods must be delivered to the consumer with clarity, simplicity, and trustworthiness. Successful communication strategies and advertising 
campaigns on promoting good animal welfare and the positive effects of organic farming on the environment could increase the number of people opting for organic foods. Particularly, the product packaging must include text / graphic elements referring to the concepts of environmental sustainability and animal welfare (Scozzafava et al., 2020).

The relationship between humans and the environment is becoming worse. Unless individuals change their behaviours, the degradation of general well-being of the people, and the environment, can be expected. This study contributes further information regarding the implications of promoting environmental knowledge and education.

The outcomes of this study show how the students' decision to purchase organic food is affected by their own knowledge, attitude, and behaviour toward the environment. Moreover, students may care a great deal for the environment regardless of their social status. Further studies on pro-environmental attitudes can contribute to the understanding of organic buying among nutrition and dietetic students. Overall, the findings in this study are consistent with previous studies, which support that the concern for the environment is the determining factor of an individual's decision in purchasing organic foods (Melovic, Dabic, Rogic, Durisic, and Prorok, 2020; Olsen, Thach, and Hemphill, 2012; Paul and Rana, 2012; Saleki, Quoquab, and Mohammad, 2019).

\section{Conclusions}

Dieticians can provide information on benefits of consuming organic foods. In turn, this can stimulate agricultural production and an increase in the number of organic restaurant menus. However, there are several limitations for this study. The findings of this research may not be applicable to other students from different departments. It is also important to note that the questionnaire was not able to collect information about the consumers' health perspective on organic food, how these were linked to their stated preference, and types of food (i.e. animal products, vegetables and fruits). Finally, the present research's model did not consider the effect of the demographic variables. Therefore, it is suggested that future studies integrate gender, age, department into the present study model and explore their influences. 
This study then postulates that nutrition and dietetic students prefer organic food. Furthermore, the findings of this study could contribute to the collective knowledge on the environment and the benefits of organic foods, in the health education context.

\section{Acknowledgements}

The authors acknowledge the participants who volunteered to be a part of this research project.

\section{Disclosure statement}

No potential conflict of interest was reported by the authors.

\section{References}

Aertsens, J., Verbeke, W., Mondelaers, K. and Huylenbroeck, G. V. (2009). Personal determinants of organic food consumption: A review. British Food Journal, 111(10), 1140-1167.

Afonso, C., Gavilán, D., Martins Gonçalves, H. and García de Madariaga, J. (2017). Why consumers purchase organic products? The role of environment, health and age. Paper presented at the XXIX Congreso de Marketing AEMARK (2017), p.36-50.

Akgüngör, S., Miran, B. and Abay, C. (2010). Consumer willingness to pay for organic food in Urban Turkey. Journal of International Food and Agribusiness Marketing, 22(3-4), 299-313. doi:10.1080/08974431003641455.

Bamberg, S. and Möser, G. (2007). Twenty years after Hines, Hungerford, and Tomera: A new meta-analysis of psycho-social determinants of proenvironmental behaviour. Journal of Environmental Psychology, 27(1), 1425.

Baumann, S., Engman, A., Huddart-Kennedy, E. and Johnston, J. (2017). Organic vs. local: Comparing individualist and collectivist motivations for "ethical" food consumption. Canadian Food Studies/La Revue canadienne des études sur l'alimentation, 4(1), 68-86. 
Boz, I. and Kaynakçı, C. (2019). Possibilities of Improving organic farming in Turkey. Paper presented at the Proceedings Book, 3th International Conference on Food and Agricultural Economics.

Bramer, W. M., de Jonge, G. B., Rethlefsen, M. L., Mast, F. and Kleijnen, J. (2018). A systematic approach to searching: An efficient and complete method to develop literature searches. Journal of the Medical Library Association: JMLA, 106(4), 531-541. doi:10.5195/jmla.2018.283.

Braun, T. (2018). Efficacy of Outdoor environmental education: A Cross-national comparative research study investigating nature connectedness, environmental attitudes, knowledge and behavior. Doctoral Thesis, Universitätsbibliothek Johann Christian Senckenberg.

Chang, C. (2011). Feeling ambivalent about going green. Journal of Advertising, 40(4), 19-32.

Chen, F.-Y. (2013). The intention and determining factors for airline passengers' participation in carbon offset schemes. Journal of Air Transport Management, 29, 17-22.

Çabuk, S., Tanrikulu, C. and Gelibolu, L. (2014). Understanding organic food consumption: Attitude as a mediator. International Journal of Consumer Studies, 38(4), 337-345. doi:10.1111/ijcs.12094.

Drissner, J., Haase, H. M. and Hille, K. (2010). Short-term environmental education-does it work? An evaluation of the 'green classroom'. Journal of Biological Education, 44(4), 149-155.

EU. (2018). Organic farming legislation - Revision of EU Regulation on organic production and labelling of organic products. https://www.europarl.europa.eu/thinktank/en/document.html? reference $=E P$ RS_BRI\%282018\%29614743. Accessed 01.10.2020.

Forman, J. and Silverstein, J. (2012). Organic foods: health and environmental advantages and disadvantages. Pediatrics, 130(5), 1406-1415.

Ghali-Zinoubi, Z. (2020). On linking socioeconomic status to consumer willingness to buy and pay for organic food. Journal of Food Science and Technology, 58(3), 1042-1050. doi:10.1007/s13197-020-04618-9.

Gifford, R., Sussman, R. and Clayton, S. (2012). The Oxford Handbook of Environmental and Conservation Psychology. In: Oxford University Press, USA.

Hadzigeorgiou, Y., Prevezanou, B., Kabouropoulou, M. and Konsolas, M. (2011). Teaching about the importance of trees: A study with young children. Environmental Education Research, 17(4), 519-536. 
Harding, B. A. (2016). Considering Efficacy of an outdoor environmental education program: Facilitating elementary students' environmental knowledge, attitudes, and behaviours. In: Kingston: Queen's University Kingston.

ICDA. (2010). Role of dietitians in food sustainability: Position of the Italian Association of Dietitians (ANDID). National Association Reports.

Indriani, I. A. D., Rahayu, M. and Hadiwidjojo, D. (2019). The Influence of Environmental Knowledge on Green Purchase Intention the Role of Attitude as Mediating Variable. International Journal of Multicultural and Multireligious Understanding, 6(2), 627-635.

Johnson, B. and Manoli, C. C. (2010). The 2-MEV scale in the United States: a measure of children's environmental attitudes based on the theory of ecological attitude. The Journal of Environmental Education, 42(2), 84-97.

Kaiser, F. G., Roczen, N. and Bogner, F. X. (2008). Competence formation in environmental education: Advancing ecology-specific rather than general abilities. Umweltpsychologie, 12(2), 56-70.

Katt, F. and Meixner, O. (2020). A systematic review of drivers influencing consumer willingness to pay for organic food. Trends in Food Science and Technology, 100, 374-378.

Kollmuss, A. and Agyeman, J. (2002). Mind the gap: Why do people act environmentally and what are the barriers to pro-environmental behavior? Environmental Education Research, 8(3), 239-260.

Konuk, F. A. (2018). Antecedents of pregnant women's purchase intentions and willingness to pay a premium for organic food. British Food Journal, 120(7), 1561-1573.

Liefländer, A. K., Bogner, F. X., Kibbe, A. and Kaiser, F. G. (2015). Evaluating environmental knowledge dimension convergence to assess educational programme effectiveness. International Journal of Science Education, 37(4), 684-702.

Lozano, R., Lozano, F. J., Mulder, K., Huisingh, D. and Waas, T. (2013). Advancing higher education for sustainable development: international insights and critical reflections. In: Elsevier.

MAF, R. o. T. (2020). 2018 yılı organik tarım istatistikleri.

Manoli, C. C., Johnson, B., Hadjichambis, A. C., Hadjichambi, D., Georgiou, Y. and Ioannou, H. (2014). Evaluating the impact of the Earthkeepers Earth education program on children's ecological understandings, 
values and attitudes, and behaviour in Cyprus. Studies in Educational Evaluation, 41, 29-37.

Mantzicopoulos, P. and Patrick, H. (2011). Reading picture books and learning science: Engaging young children with informational text. Theory Into Practice, 50(4), 269-276.

Melovic, B., Dabic, M., Rogic, S., Durisic, V. and Prorok, V. (2020). Food for thought Identifying the influential factors that affect consumption of organic produce in today's youth. British Food Journal, 122(4), 1130-1155.

Muhammad, S., Fathelrahman, E., Ullah, T. and Ullah, R. (2016). The significance of consumer's awareness about organic food products in the United Arab Emirates. Sustainability, 8(9), 833.

Olsen, J., Thach, L. and Hemphill, L. (2012). The impact of environmental protection and hedonistic values on organic wine purchases in the US. International Journal of Wine Business Research, 24(1), 47-67.

Oraman, Y. and Unakitan, G. (2010). Analysis of factors influencing organic fruit and vegetable purchasing in Istanbul, Turkey. Ecology of Food and Nutrition, 49(6), 452-466. doi:10.1080/03670244.2010.524105.

Paul, J. and Rana, J. (2012). Consumer behavior and purchase intention for organic food. Journal of consumer Marketing, 29(6), 412-422.

Saleki, R., Quoquab, F. and Mohammad, J. (2019). What drives Malaysian consumers' organic food purchase intention? The role of moral norm, self-identity, environmental concern and price consciousness. Journal of Agribusiness in Developing and Emerging Economies, 9(5), 584-603.

Scozzafava, G., Gerini, F., Boncinelli, F., Contini, C., Marone, E. and Casini, L. (2020). Organic milk preference: Is it a matter of information? Appetite, 144, 104477. doi:https://doi.org/10.1016/j.appet.2019.104477.

Shahbandeh, M. (2020). Area of organic farming worldwide 2000-2018.

Sharma, N. and Singhvi, R. (2018). Consumers perception and Behaviour towards organic food: A systematic review of literature. Journal of Pharmacognosy and Phytochemistry, 7(2), 2152-2155.

Smith-Spangler, C., Brandeau, M. L., Hunter, G. E., Bavinger, J. C., Pearson, M., Eschbach, P. J. and Stave, C. (2012). Are organic foods safer or healthier than conventional alternatives?: A systematic review. Annals of Internal Medicine, 157(5), 348-366.

Szerényi, Z., Ágnes, Z. and Anna, S. (2011). Consumer behaviour and lifestyle patterns of Hungarian students with regard to environmental awareness. Society and Economy, 33(1), 89-109. 
Thalheimer, J. C. and RD, L. (2013). The organic foods debate: Are they healthier than conventional. Today's Dietitian, 15(7), 28.

Wheeler, S. A., Gregg, D. and Singh, M. (2019). Understanding the role of social desirability bias and environmental attitudes and behaviour on South Australians' stated purchase of organic foods. Food Quality and Preference, $\quad 74, \quad 125-134$. doi:https://doi.org/10.1016/j.foodqual.2019.01.007.

Zsóka, Á., Szerényi, Z. M., Széchy, A. and Kocsis, T. (2013). Greening due to environmental education? Environmental knowledge, attitudes, consumer behavior and everyday pro-environmental activities of Hungarian high school and university students. Journal of Cleaner Production, 48, 126-138. doi:https://doi.org/10.1016/j.jclepro.2012.11.030.

\section{Citation Information}

Unusan, N. ve Tekindal, M. A. (2021). Environmental education, attitudes, and behaviours of nutrition and dietetics students on buying organic foods. OPUS-International Journal of Society Studies, 18(43), 6177-6194. DOI: 10.26466/opus.872561. 